\title{
Kinetika Fotodegradasi Remazol Yellow Menggunakan Zeolit A Terimpregnasi $\mathrm{TiO}_{2}$
}

\author{
Suhardi Titdoy a, Audy D. Wuntu a*, Vanda S. Kamu a \\ aJurusan Kimia, FMIPA, Unsrat, Manado
}

\begin{tabular}{l} 
K A T A K UN C I \\
\hline fotodegradasi \\
remazol yellow \\
zeolit A \\
$\mathrm{TiO}_{2}$
\end{tabular}

\begin{abstract}
A B S TRAK
Telah dilakukan penelitian tentang kinetika fotodegradasi remazol yellow dengan menggunakan zeolit A terimpregnasi $\mathrm{TiO}_{2}$. Jumlah $\mathrm{TiO}_{2}$ divariasikan dalam perbandingan berat zeolit $\mathrm{A}: \mathrm{TiO}_{2}$ sebesar 1:0.4, 1:0.6, 1:0.8, 1:1, 1:1.2, dan 1:1,4 g/g. Eksperimen kinetika dilakukan melalui penentuan konsentrasi remazol yellow yang tersisa setelah interaksi zeolit A : $\mathrm{TiO}_{2}$ dengan larutan remazol yellow yang disinari UV pada waktu 10 , 20, 30, 40, 50, 60, dan 90 menit. Selanjutnya data dianalisis mengikuti model kinetika reaksi orde-1. Hasil penelitian menunjukan bahwa semakin tinggi jumlah $\mathrm{TiO}_{2}$ dalam material zeolit $\mathrm{A}$ : $\mathrm{TiO}_{2}$ maka semakin kecil laju fotodegradasi. Perbandingan berat 1:0,4 menghasilkan laju fotodegradasi paling besar dengan konstanta laju sebesar 0,0184 menit-1.

A B S TR A C T

$A$ research on photodegradation kinetics of remazol yellow using $\mathrm{TiO}_{2}$ impregnated A-type zeolite has been done. The amount of $\mathrm{TiO}_{2}$ was varied in weight ratio of zeolite $\mathrm{A}: \mathrm{TiO}_{2}$ which were 1:0.4, 1:0.6, 1:0.8, 1:1, 1:1.2, and $1: 1.4 \mathrm{~g} / \mathrm{g}$. Kinetics experiment was performed by determining the concentration of remazol yellow remained after the interaction of zeolite $\mathrm{A}$ : $\mathrm{TiO}_{2}$ with remazol yellow solution that is illuminated by UV-light at 10,20 , 30, 40, 50, 60 and 90 minutes. Data obtained was analyzed using firstorder reaction kinetics model. The results showed that the higher the amount of $\mathrm{TiO}_{2}$ in the mixture of zeolite $\mathrm{A}: \mathrm{TiO}_{2}$ material, the smaller the rate of photodegradation. The weight ratio of 1:0.4 produced the greatest rate of photodegradation with rate constant of $0.0184 \mathrm{~min}^{-1}$..
\end{abstract}

\section{K E Y W O R D S}

photodegradation

remazol yellow

A-type zeolite

$\mathrm{TiO}_{2}$
TERSEDIA ONLINE

27 Januari 2016

\section{Pendahuluan}

Industri tekstil dan produk tekstil merupakan salah satu bidang yang sangat berkembang pesat di Indonesia. Seiring dengan berkembangnya industri tekstil, terdapat masalah serius yang sering membawa dampak buruk terhadap lingkungan, khususnya masalah yang diakibatkan oleh limbah cair yang dihasilkan, seperti halnya limbah cair zat warna yang hanya dibuang tanpa adanya proses pengolahan lebih lanjut yang dapat berdampak mencemari lingkungan perairan.

Limbah cair dapat berasal dari proses-proses industri seperti industri metalurgi, industri penyamakan kulit, industri cat dan zat warna tekstil
(Redhana, 1994). Limbah zat warna yang dihasilkan dari industri tekstil biasanya merupakan senyawa organik yang tidak mengalami biodegradasi dan dapat menyebabkan pencemaran lingkungan terutama lingkungan perairan (Wijaya et al., 2006).

Zat warna juga merupakan senyawa organik yang mengandung gugus kromofor terkonjugasi. Zat warna reaktif merupakan zat warna yang banyak digunakan untuk pewarnaan tekstil, contohnya remazol brilliant orange $3 R$, remazol yellow, remazol red, dan remazol black $B$. Zat-zat warna tersebut sering digunakan untuk proses pewarnaan batik baik dalam skala industri besar maupun industri rumahan (Nugroho et al., 2013). Remazol yellow mewakili salah satu zat warna pilihan dalam 
pewarnaan batik karena memberikan warna yang cerah dan tidak mudah luntur (Qodri, 2011).

Salah satu metode yang relatif murah dan mudah diterapkan adalah fotodegradasi. Metode fotodegradasi merupakan metode yang efektif karena diketahui dapat menguraikan senyawa zat warna menjadi senyawa yang tidak berbahaya seperti $\mathrm{H}_{2} \mathrm{O}$ dan $\mathrm{CO}_{2}$ (Slamet et al.,2006). Metode fotodegradasi dapat dilakukan dengan menggunakan katalis berupa semikonduktor. Katalis semikonduktor yang sering digunakan adalah $\mathrm{TiO}_{2}, \mathrm{ZnO}$, CdS dan $\mathrm{Fe}_{2} \mathrm{O}_{3}$. $\mathrm{TiO}_{2}$ adalah katalis semikonduktor yang paling efektif karena mempunyai celah energi relatif besar (3,2 eV) yang cocok digunakan sebagai fotokatalis, tidak beracun, harganya terjangkau dan melimpah di alam (Joshi dan Shirivasta, 2010). Fotokatalisis $\mathrm{TiO}_{2}$ kurang maksimal jika digunakan dalam keadaan murni karena mempunyai luas permukaan yang relatif rendah. Dengan demikian maka $\mathrm{TiO}_{2}$ perlu diimpregnasi pada suatu adsorben (Slamet et al., 2008).

Berdasarkan penelitian yang telah dilakukan Andarini (2012) dan Ramadhana (2013), aktivitas fotokatalis $\mathrm{TiO}_{2}$ dapat ditingkatkan melalui impregnasi pada material pendukung seperti adsorben. Salah satu adsorben yang sering digunakan adalah zeolit alam dengan material $\mathrm{TiO}_{2}$ terimpregnasi pada zeolit alam yang menghasilkan adsorben yang dapat menjerap sekaligus mampu menguraikan zat warna seperti methyl orange. Penelitian yang dilakukan oleh Damayanti (2014) menunjukkan bahwa konsentrasi $\mathrm{TiO}_{2}$ terimpregnasi dalam zeolit berpengaruh terhadap laju degradasi zat warna methylene blue dan efektif digunakan kembali untuk beberapa kali pemakaian dalam proses fotodegradasi.

Pada penelitian ini digunakan zeolit A sintetik yang diimpregnasi dengan $\mathrm{TiO}_{2}$. (Poluakan, et al., 2015) sebelumnya telah menggunakan arang aktif yang di impregnasi dengan $\mathrm{TiO}_{2}$ sedangkan (Tumbel, et al., 2015) telah menggunakan zeolit A terimpregnasi $\mathrm{TiO}_{2}$ untuk mendegradasi remazol yellow. Meskipun demikian, pada penelitian tersebut belum diuji laju fotodegradasi remazol yellow dengan menggunakan zeolit $\mathrm{A}$ terimpregnasi $\mathrm{TiO}_{2}$. Pada penelitian ini ditentukan pengaruh perbandingan berat zeolit $\mathrm{A} / \mathrm{TiO}_{2}$ pada laju fotodegradasi remazol yellow oleh zeolit $A$ terimpregnasi $\mathrm{TiO}_{2}$.

\section{Material dan Metode}

\subsection{Bahan dan Alat}

Peralatan yang digunakan adalah spektrofotometer UV-Vis (Shimadzu UV-1800), lampu UV - A (Himawari T8 - $20 \mathrm{~W}$ ), sentrifus (Gemmy PLC- 025), timbangan analitik (Adam PW 254), alat-alat gelas (Iwaki Pyrex). Bahan-bahan yang digunakan adalah zat warna remazol yellow, titanium dioksida, zeolit A dan akuades.

\subsection{Prosedur}

Material zeolit A dipreparasi mengikuti prosedur yang dikemukakan oleh Wuntu (2002) dan impregnasi $\mathrm{TiO}_{2}$ pada zeolit dikerjakan mengikuti prosedur yang dikemukakan oleh Andari dan Wardhani (2014). Zat warna dalam medium berukuran $500 \mathrm{~mL}$ dibuat dalam konsentrasi $40 \mathrm{ppm}$, kemudian larutan zat warna tersebut di ambil $20 \mathrm{~mL}$ dan dimasukkan ke dalam beberapa botol serum yang telah disiapkan. Selanjutnya material dengan perbandingan zeolit A $\mathrm{TiO}_{2}(1: 0,4)$ ditimbang sebanyak 0,05 gram lalu dimasukkan ke dalam masing-masing medium, dan diletakkan ke dalam reaktor dan diberi sumber sinar dari lampu UV dengan variasi waktu lama penyinaran yaitu 10, 20, 30, 40, 50, 60, 90 menit. Setelah itu dilakukan penyaringan dan filtrat disentrifugasi selama 30 menit dengan kecepatan putaran 3200 rpm. Konsentrasi zat warna dalam larutan setelah sentrifugasi selanjutnya dianalisis dengan spektrofotometer UV-Vis pada panjang gelombang 414 $\mathrm{nm}$ (panjang gelombang di mana zat warna remazol yellow menghasilkan adsorbans paling besar). Prosedur yang sama dilakukan untuk zeolit $\mathrm{A}: \mathrm{TiO}_{2}$ dengan perbandingan 1:0,6;1:0,8; 1:1; 1:1,2; dan $1: 1,4$. Data yang diperoleh selanjutnya dianalisis menggunakan model kinetika reaksi order ke-satu untuk menentukan konstanta laju :

$$
\mathrm{C}_{\mathrm{t}}=\mathrm{C}_{0} \mathrm{e}^{-\mathrm{kt}} \text { atau } \ln \left(\mathrm{C}_{\mathrm{t}} / \mathrm{C}_{0}\right)=-\mathrm{kt}
$$

dengan $\mathrm{Ct}_{\mathrm{t}}$ adalah konsentrasi zat warna yang tersisa pada waktu t, Co adalah konsentrasi awal zat warna, dan $\mathrm{k}$ adalah konstanta laju reaksi. Dengan membuat kurva - $\ln \left(\mathrm{Ct}_{\mathrm{t}} / \mathrm{C}_{0}\right)$ vs. t maka dapat ditentukan kemiringan kurva yang merepresentasikan konstanta laju reaksi, $\mathrm{k}$.

\section{Hasil dan Pembahasan}

\subsection{Pengaruh material zeolit $\mathrm{A}-\mathrm{TiO}_{2}$ pada konsentrasi remazol yellow}

Penggunaan material zeolit $\mathrm{A}-\mathrm{TiO}_{2}$ dengan berbagai perbandingan zeolit $\mathrm{A} / \mathrm{TiO}_{2}$ pada larutan zat warna remazol yellow yang diradiasi ultraviolet menyebabkan terjadinya penurunan konsentrasi zat warna (Gambar 1). Data penurunan konsentrasi remazol yellow menunjukkan kesesuaian paling tinggi dengan kecenderungan penurunan konsentrasi yang mengikuti regresi logaritmik. Regresi logaritmik merupakan bentuk regresi yang menggambarkan laju perubahan data yang tidak konstan tapi mengalami kenaikan atau penurunan dengan cepat dan kemudian melambat yang ditandai dengan bentuk kurva mendekati datar.

Pada Gambar 1 terlihat bahwa pada setiap waktu pengukuran tertentu, material zeolit $\mathrm{A}-\mathrm{TiO}_{2}$ dengan perbandingan berat zeolit $\mathrm{A} / \mathrm{TiO}_{2}$ 1:0,4 memberikan penurunan konsentrasi remazol yellow paling besar. Material yang mengandung $\mathrm{TiO}_{2}$ dalam 
jumlah paling banyak, yaitu pada perbandingan berat 1:1,2 dan 1:1,4 menghasilkan penurunan konsentrasi remazol yellow paling kecil. Berkurangnya kemampuan fotodegradasi dengan bertambahnya jumlah $\mathrm{TiO}_{2}$ dalam material zeolit A $\mathrm{TiO}_{2}$ berkaitan dengan luas permukaan spesifik dan volume total pori zeolit. Luas permukaan spesifik adalah total luas permukaan per satuan massa atau volume material adsorben zeolit. Dalam penelitiannya, Fatimah dan Wijaya (2005) mengemukakan bahwa luas permukaan spesifik material merupakan salah satu faktor yang mempengaruhi fotoaktivitas material zeolit- $\mathrm{TiO}_{2}$ terkait dengan distribusi $\mathrm{TiO}_{2}$ dalam material tersebut. Fatimah et al. (2006) kemudian menunjukkan bahwa penambahan $\mathrm{TiO}_{2}$ ke dalam struktur zeolit alam menyebabkan terjadinya penurunan luas permukaan spesifik dan volume total pori zeolit. Selanjutnya dikemukakan bahwa hal tersebut dapat disebabkan oleh terjadinya penggumpalan atau penggabungan partikel-partikel $\mathrm{TiO}_{2}$ dan terjadinya penutupan pori zeolit oleh partikel $\mathrm{TiO}_{2}$. Semakin banyak jumlah $\mathrm{TiO}_{2}$ maka semakin besar kemungkinan terjadinya penggumpalan dan penutupan pori zeolit oleh $\mathrm{TiO}_{2}$.

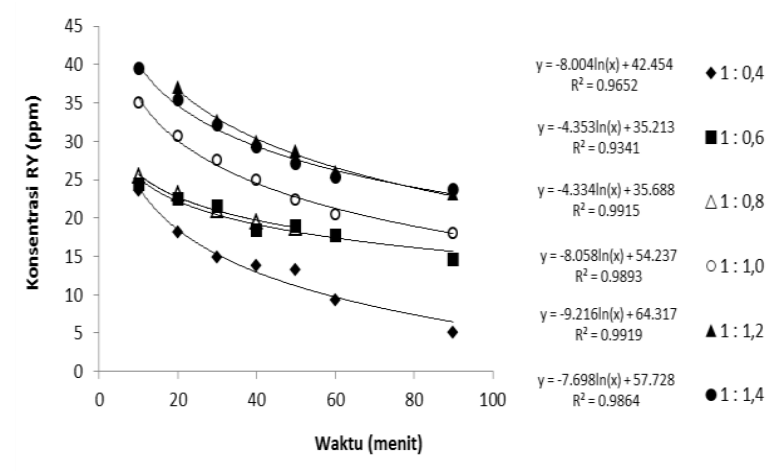

Gambar 1. Penurunan konsentrasi zat warna remazol yellow oleh zeolit $A$ terimpregnasi $\mathrm{TiO}_{2}$ dengan perbandingan berat zeolit $\mathrm{A} / \mathrm{TiO}_{2}$ antara 1:0,4 hingga 1:1,4 selama periode waktu 10 hingga 90 menit

Pada material zeolit $\mathrm{A}-\mathrm{TiO}_{2}$ terjadi dua proses utama, yaitu adsorpsi yang menyebabkan terikatnya zat warna pada permukaan zeolit dan kemudian diikuti dengan degradasi zat warna pada permukaan zeolit oleh $\mathrm{TiO}_{2}$ yang diimpregnasi pada zeolit. Berkurangnya luas permukaan spesifik pada zeolit dapat menyebabkan berkurangnya jumlah zat warna yang dapat diadsorpsi pada permukaan zeolit dan pada gilirannya menurunkan jumlah zat warna yang dapat didegradasi oleh $\mathrm{TiO}_{2}$.

\subsection{Kinetika fotodegradasi remazol yellow}

Data yang diperoleh selanjutnya dianalisis menggunakan model kinetika reaksi order ke-satu dengan membuat regresi linear $-\ln \left(\mathrm{C}_{\mathrm{t}} / \mathrm{C}_{0}\right)$ vs. $\mathrm{t}$ (Gambar 2) di mana $\mathrm{Ct}_{\mathrm{t}}$ adalah konsentrasi zat warna pada waktu t, Co adalah konsentrasi zat warna sebelum fotodegradasi, sedangkan nilai konstanta laju reaksi, $\mathrm{k}$, dapat diperoleh dari nilai kemiringan (slope) pada persamaan linear tersebut.

Gambar 2 menunjukkan bahwa konstanta laju fotodegradasi semakin kecil dengan naiknya jumlah $\mathrm{TiO}_{2}$ dalam material zeolit $\mathrm{A}-\mathrm{TiO}_{2}$. Laju fotodegradasi paling cepat terjadi pada penggunaan material zeolit $\mathrm{A}$ - $\mathrm{TiO}_{2}$ dengan perbandingan berat zeolit $\mathrm{A} / \mathrm{TiO}_{2}$ 1:0,4 yang memberikan nilai konstanta laju, k, paling besar $\left(0,0184\right.$ menit-1 $^{-1}$. Material dengan perbandingan berat zeolit $\mathrm{A} / \mathrm{TiO}_{2}$ 1:1,2 dan 1:1,4 menghasilkan laju fotodegradasi paling lambat dengan nilai konstanta laju, k, yang sama yaitu 0,0065 menit-1.

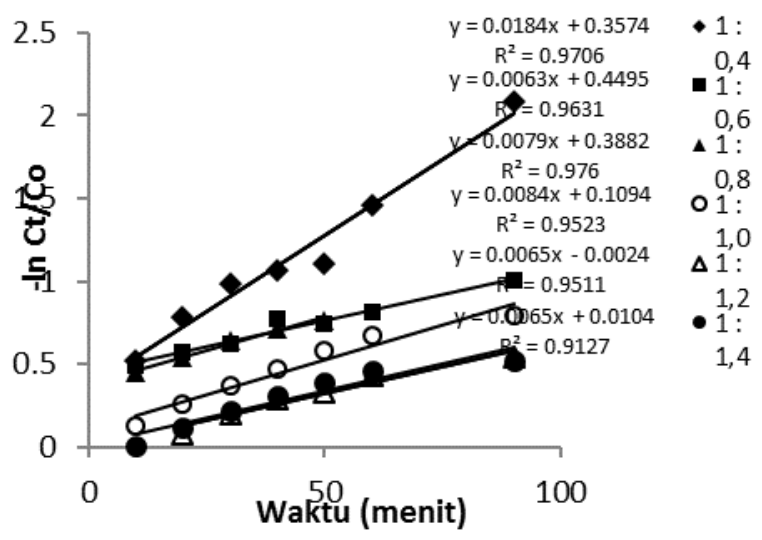

Gambar 1. Plot $-\ln \left(\mathrm{C}_{t} / \mathrm{C}_{0}\right)$ vs. $\mathrm{t}$ untuk fotodegradasi remazol yellow menggunakan beberapa perbandingan berat zeolit $\mathrm{A} / \mathrm{TiO}_{2}$

Penelitian Chen dan Ray (1998) mengenai fotodegradasi 4-nitrofenol dalam suspensi $\mathrm{TiO}_{2}$ menunjukkan bahwa nilai konstanta laju reaksi semakin besar dengan naiknya konsentrasi $\mathrm{TiO}_{2}$ sampai pada nilai tertentu, namun pada konsentrasi $\mathrm{TiO}_{2}$ yang tinggi terjadi penurunan konstanta laju reaksi. Penurunan laju reaksi pada kasus ini juga dapat terjadi karena pada konsentrasi tinggi terbentuk agregat $\mathrm{TiO}_{2}$ yang menghambat fotodegradasi.

Telah diketahui bahwa saat $\mathrm{TiO}_{2}$ disinari radiasi dengan panjang gelombang $\lambda<380 \mathrm{~nm}$ dalam medium air yang mengandung oksigen terlarut dan senyawa organik, maka senyawa organik akan mengalami fotodegradasi. Tahap pertama dalam proses fotodegradasi adalah pelepasan elektron (e-) dari pita valensi yang berpindah ke pita konduksi sehingga meninggalkan "lubang" bermuatan positif $\left(\mathrm{h}^{+}\right)$. Dengan adanya oksigen terlarut dan suatu donor elektron, maka terbentuk radikal $\mathrm{OH}^{\bullet}$ melalui reaksi antara $\mathrm{h}^{+}$dengan gugus $\mathrm{OH}^{-}$atau molekul air di permukaan $\mathrm{TiO}_{2}$. Di lain pihak, e- yang ada di pita konduksi dapat bereaksi dengan $\mathrm{O}_{2}$ terlarut membentuk ion superoksida $\mathrm{O}_{2}^{-}$. Radikal $\mathrm{OH}^{\bullet}$ yang terbentuk selanjutnya akan mengoksidasi zat warna.

$$
\mathrm{TiO}_{2}+\mathrm{hu} \rightarrow \mathrm{h}^{+}+\mathrm{e}
$$




$$
\begin{aligned}
& \mathrm{h}^{+}+\mathrm{OH}^{-} \rightarrow \mathrm{OH}^{\bullet} \\
& \mathrm{h}^{+}+\mathrm{H}_{2} \mathrm{O} \rightarrow \mathrm{OH}^{\bullet}+\mathrm{H}^{+} \\
& \mathrm{OH}^{\bullet}+\text { zat warna } \rightarrow \mathrm{CO}_{2}+\mathrm{H}_{2} \mathrm{O} \text { (produk) }
\end{aligned}
$$

Selama $\mathrm{TiO}_{2}$ menerima radiasi tersebut, elektron akan terus tereksitasi dan fotodegradasi akan terus berlangsung. Dengan terjadinya agregasi atau penggumpalan $\mathrm{TiO}_{2}$ maka jumlah $\mathrm{TiO}_{2}$ yang menerima radiasi menjadi lebih sedikit sehingga lebih sedikit elektron terlepas dan lebih sedikit "lubang" positif yang terbentuk. Faktor ini, dikombinasikan dengan terjadinya penurunan luas permukaan dan total pori zeolit akibat agregasi $\mathrm{TiO}_{2}$ dapat menyebabkan penurunan laju fotodegradasi zat warna.

\section{Kesimpulan}

Material zeolit A - $\mathrm{TiO}_{2}$ dapat digunakan sebagai agen fotodegradasi untuk menurunkan konsentrasi zat warna remazol yellow dalam larutan dengan pelarut air. Konsentrasi remazol yellow yang tersisa dalam larutan setelah radiasi ultraviolet sebagai fungsi waktu fotodegradasi memperlihatkan kecenderungan penurunan secara logaritmik di mana fotodegradasi pada awalnya terjadi secara cepat kemudian diikuti penurunan laju fotodegradasi. Pada kisaran perbandingan berat zeolit $\mathrm{A} / \mathrm{TiO}_{2}$ antara 1:0,4 hingga 1:1,4, semakin besar jumlah $\mathrm{TiO}_{2}$ dalam material semakin lambat laju fotodegradasi remazol yellow. Perbandingan berat zeolit $\mathrm{A} / \mathrm{TiO}_{2}$ 1:0,4 menghasilkan laju fotodegradasi paling besar.

\section{Daftar Pustaka}

Andari, D.N., dan S. Wardhani. 2014. Fotokatalis $\mathrm{TiO}_{2}$ - Zeolit Untuk Degradasi Metilen Biru. Chem.Prog. 1:9-14.

Chen D., Ray A. K. 1998. Photodegradation Kinetics of 4-Nitrofenol in $\mathrm{TiO}_{2}$ Suspension. Depertement of Chemical Engineering. National University of Singapore. Vol.32. No.11. pp. 3223-3234.

Damayanti, C., A., Wardhani, S., dan Purwonugroho, D. 2014. Pengaruh Konsentrasi $\mathrm{TiO}_{2}$ Dalam Zeolit Terhadap Degradasi Methylene Blue Secara Fotokatalitik. Kimia Student Jurnal 1 (1) : 8-14

Fatimah, I. dan Huda, T., Sintesis Dan Aplikasi Montmorillonit Termodifikasi TiO 2 Sebagai Fotokatalis Pada Pengolahan Limbah Cair Industri Tekstil, Prosiding Seminar Nasional Kimia II, diselenggarakan oleh Jurusan IImu Kimia FMIPA UII, ISBN: ISBN No: 979-96595-1-5, hal 337-346.

Nugroho, S., A.T. Prasetya, dan S. Wahyuni. 2013. Elektrodegradasi Indigosol Golden Yellow IRK Dalam Limbah Batik Dengan Elektoda Grafit. Indonesian Journal of Chemical Science. 3:248252.

Qodri, A.A. 2011. Fotodegradasi Zat Warna Remazol Yellow Dengan Fotokatalis Komposit $\mathrm{TiO}_{2} / \mathrm{SiO}_{2}$ [skripsi]. FMIPA UNS, Surakarta.

Redhana, I.W. 1994. Penentuan Isoterm Adsorpsi Amonia dalam Larutan Air oleh Karbon Aktif pada Suhu Kamar. Laporan Penelitian. Program Pra-S2 Kimia, Pasca Sarjana, ITB, Bandung .

Slamet, Ellyana, M., Bismo, S. 2008. Modifikasi Zeolit Alam Lapung dengan Fotokatalis $\mathrm{TiO}_{2}$ Melalui Metode Sol Gel dan Aplikasinya untuk Penyisihan Fenol. Departemen Teknik Kimia, Fakultas Teknik, Universitas Indonesia.

Wijaya, K. 2006. Utilisasi $\mathrm{TiO}_{2}$ dan Sinar UV untuk Fotodegradasi Zat Warna Congo Red. TEKNOIN. 11(3) :199-209.

Wuntu, A.D. 2002. Sintesis dan Karakterisasi Aluminosilikat Serupa Zeolit. Jurnal IImiah Sains. 2:4-7. 